\title{
Bidirectional Relationship between COVID-19 and Diabetes
}

\author{
Ahmed M Abbas ${ }^{1,2 *}$, Reem Sayad ${ }^{2,3}$, Fatma A Omar ${ }^{2,4}$ and Lobna Ahmed ${ }^{2,4}$ \\ ${ }^{1}$ Department of Obstetrics \& Gynecology, Faculty of Medicine, Assiut University, Egypt \\ ${ }^{2}$ Covid-19 Research of Assiut University Association (CORAUNA), Egypt. \\ ${ }^{3}$ Under-graduate, Faculty of Medicine, Assiut University, Egypt. \\ ${ }^{4}$ House-officer, Faculty of Medicine, Assiut University, Egypt.
}

*Corresponding author: Ahmed M Abbas, Professor at Department of Obstetrics and Gynecology, Assiut University, Egypt.

To Cite This Article: Ahmed M Abbas. Bidirectional Relationship between COVID-19 and Diabetes. 2020 - 9(6). AJBSR.MS.ID.001442. DOI: 10.34297/AJBSR.2020.09.001442.

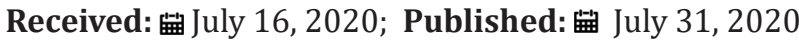

\begin{abstract}
In December 2019, novel coronavirus 2019 has appeared in china, eventually spread to other countries. Many studies on COVID-19 have reported its strong relationship with Diabetes Mellitus (DM). It is discovered that not only diabetes is a key risk factor for developing severe COVID-19, but also the virus might trigger DM in some cases. The aim of this review to show the bidirectional relationship between COVID-19 and DM.
\end{abstract}

Key words: COVID-19, Bidirectional relationship, Diabetes, Diabetes Mellitus, Single-stranded RNA viruses, Ketoacidosis, Hyperosmolarity, Glucose homeostasis, Renin Angiotensin System, Pathophysiological

\section{Introduction}

Coronaviruses are enveloped, positive single-stranded RNA viruses widely distributed in humans and animals worldwide [1]. The outbreak of a new coronavirus, termed officially by the World Health Organization (WHO) coronavirus disease-2019 (COVID-19) and the international committee on taxonomy of viruses has suggested SARS-CoV-2 as the name of the virus that causes COVID-19. There is many cases and deaths especially from its first identifications in Wuhan, china, in December 2019 [2-4]. Because of this continuous increase in numbers, COVID-19 has become the focus of attention of many scientists and researchers. Through the studies done on the cases of COVID-19, it was found that Diabetes Mellitus (DM) is not only a key risk factor for developing COVID-19 [5], but also the virus might trigger DM in some cases and severe metabolic complications of preexisting diabetes such as diabetic ketoacidosis and hyperosmolarity for which exceptionally high doses of insulin are warranted [6-8]. This is expected for COVID-19 virus, because through our experience in dealing with previous coronaviruses (SARS and MERS), it was found that they also have a relationship with diabetes onset [9].

Diabetes is one of the leading causes of morbidity and mortality throughout the world due to its several macrovascular and microvascular complications that finally impact the overall patient's survival [10] Characteristic feature of DM is hyperglycemia [11]. The most common forms of DM are type 1DM, which is an organspecific autoimmune disease, schematically comprised of two phases:

A. An occult phase of pancreatic inflammation that reduces the number and function of insulin-producing $\beta$-cells, eventually provoking sufficient damage to result in

B. The overt phase of DM, when insulin production is 
insufficient for proper glucose homeostasis [12], and type 2DM, in which insulin resistance may lead to hyperglycemia [11].

In the Renin Angiotensin System (RAS), ACE is a key enzyme, which converts Angiotensin (Ang) I to the vasoconstrictor Ang II, thought to be responsible for most of the physiological and pathophysiological effects of the RAS. This classical view of the RAS was challenged with the discovery of the enzyme, AngiotensinConverting Enzyme2 (ACE2) which not only degrades Ang II, but also leads to formation of the vasodilatory and anti-proliferative peptide, Ang 1-7 [13]. The expression of the ACE-2 could increase in patients with DM and it is a major contributor to diabetic complications [13].

Individuals with DM are more likely to be infected and at a higher risk for complications and death from COVID-195 [14-16] due to human pathogenic coronaviruses bind to their target cells through ACE2, which is expressed by epithelial cells of the lung, intestine, kidney, and blood vessels [17], and its expression could increase in diabetic patients as we mentioned before.

If we consider the history of DM with infection, we find there is a recognized relationship between DM and infection a long time ago [18]. Nevertheless, the evidence remains controversial regarding whether diabetes itself indeed increases susceptibility and impacts outcomes from infections, or the cardiovascular and renal co morbidities that are frequently associated with DM are the main factors involved [19]. Diabetes and uncontrolled glycaemia were reported as significant predictors of severity and deaths in patients infected with different viruses, including the 2009 pandemic influenza A (H1N1) [20], SARS-CoV [21] and MERS-CoV [22].

As we mentioned before, SARS-CoV-2 bind to their target cells through ACE2, which is expressed in key metabolic organs and tissues, including pancreatic beta cells, adipose tissue, the small intestine, and the kidneys $[17,23]$, so it is expected that COVID-19 will impact these cells, because when the virus enter the body the immune system is stimulated to kill the virus and this will lead to the destruction of pancreatic cells as an example [24,25]. This will cause pleiotropic alterations of glucose metabolism that could complicate the pathophysiology of preexisting DM or lead to new mechanisms of disease [26]. Ketosis or ketoacidosis and induced Diabetic Ketoacidosis (DKA) are complications of DM that increased with viral infection.

\section{Conclusion}

There is a bidirectional relationship between COVID-19 and DM. ACE2 expression increases during DM and COVID-19 uses this enzyme to enter cells, so diabetes is a risk factor for COVID-19. The expression of ACE2 occurs in metabolic organs and cells such as liver and pancreatic beta cells, so when COVID-19 uses this enzyme to enter the cell this will lead to cell destruction by activated immune system against the virus and trigger DM in non-diabetic patient or worsen the case in diabetic patient.

\section{Conflict of Interest}

The authors state that there are no conflicts of interest.

\section{Reference}

1. Huang C, Wang Y, Li X, Ren L, Zhao J, et al. (2020) Clinical features of patients infected with 2019 novel coronavirus in Wuhan, China. Lancet 395(10223): 497-506.

2. Rasmussen SA, Smulian JC, Lednicky JA, Wen TS, Jamieson DJ (2020) Coronavirus Disease 2019 (COVID-19) and pregnancy: what obstetricians need to know. Am J Obstet Gynecol 222(5): 415-426.

3. WHO (2020) Coronavirus disease (COVID-19) outbreak?

4. Gorbalenya AE, Susan CB, Baric RS, Raoul JG, Christian D (2020) Severe acute respiratory syndrome-related coronavirus-the species and its viruses, a statement of the Coronavirus Study Group. BioRxiv.

5. Docherty AB, Harrison EM, Green CA, Hardwick HE, Pius R (2020) Features of 16,749 hospitalised UK patients with COVID-19 using the ISARIC WHO Clinical Characterisation Protocol. medRxiv.

6. Chee YJ, Ng SJH, Yeoh E (2020) Diabetic ketoacidosis precipitated by Covid-19 in a patient with newly diagnosed diabetes mellitus. Diabetes Res Clin Pract 164: 108166.

7. Li J, Wang X, Chen J, Zuo X, Zhang H (2020) COVID-19 infection may cause ketosis and ketoacidosis. Diabetes Obes Metab.

8. Ren H, Yang Y, Wang F, Yan Y, Shi X, et al. (2020) Association of the insulin resistance marker TyG index with the severity and mortality of COVID-19. Cardiovasc Diabetol 19: 58.

9. Yang J, Lin S, Ji X, Li Min Guo (2010) Binding of SARS coronavirus to its receptor damages islets and causes acute diabetes. Acta Diabetol 47: 193-199.

10. Williams R, Karuranga S, Malanda B, Saeedi P, Basit A, et al. (2020) Global and regional estimates and projections of diabetes-related health expenditure: results from the International Diabetes Federation Diabetes Atlas, $\left(9^{\text {th }}\right.$ edn). Diabetes Res Clin Pract 162: 108072.

11. American Diabetes Association (2015) Classification and diagnosis of diabetes. Diabetes Care 38: 8-16.

12. Atkinson MA, Eisenbarth GS Michels AW (2014) Type 1 diabetes. Lancet 383(9911): 69-82.

13. Dean RG, Burrell LM (2007) ACE2 and diabetic complications. Curr Pharm Des 13(26): 2730-2735

14. Onder G, Rezza G, Brusaferro S (2020) Case-fatality rate and characteristics of patients dying in relation to COVID-19 in Italy. JAMA 128: 104415

15. Guan WJ, Ni ZY, Hu Y, Liang WH, Ou CQ, et al. (2020) Clinical characteristics of coronavirus disease 2019 in China. N Engl J Med p. 1-13.

16. Wu Zunyou, McGoogan JM (2020) Characteristics of and important lessons from the coronavirus disease 2019 (COVID-19) outbreak in China: summary of a report of 72314 cases from the Chinese Center for Disease Control and Prevention. JAMA 323(13): 1239

17. Wan Y, Shang J, Graham R, Baric RS, Li F (2020) Receptor Recognition by the Novel Coronavirus from Wuhan: An Analysis Based on Decade-Long Structural Studies of SARS Coronavirus. J Virol 94(7): 127-200.

18. Jonathan SP, Blundell S, Harris T, Cook DG, Critchley J, (2016) Diabetes and infection: assessing the association with glycaemic control in population-based studies. Lancet Diabetes Endocrinol 4(2): 148-158. 
19. Knapp Sylvia (2013) Diabetes and infection: is there a link? A minireview. Gerontology 59(2): 99-104.

20. Schoen K, Horvat N, Guerreiro NFC, De Castro I, De Giassi KS (2019) Spectrum of clinical and radiographic findings in patients with diagnosis of H1N1 and correlation with clinical severity. BMC Infect Dis 19(1): 964.

21. Yang JK, Feng Y, Yuan MY, Yuan SY, Fu HJ, et al. (2006) Plasma glucose levels and diabetes are independent predictors for mortality and morbidity in patients with SARS. Diabet Med 23(6): 623-628.

22. Banik GR, Alqahtani AS, Booy R, Rashid H, (2016) Risk factors for severity and mortality in patients with MERS-CoV: analysis of publicly available data from Saudi Arabia. Virol Sin 31(1): 81-84.
23. Hamming I, Timens W, Bulthuis ML, Lely AT, Navis G, et al. (2004) Tissue distribution of ACE2 protein, the functional receptor for SARS coronavirus: a first step in understanding SARS pathogenesis. J Pathol 203: 631-637.

24. Soldevila G, Buscema M, Doshi M, James RF, Bottazzo GF, et al. (1991) Cytotoxic effect of IFN-gamma plus TNF-alpha on human islet cells. J. Autoimmun 4(2): 291-306.

25. Cetkovic CM, Eizirik DL (1994) TNF-alpha and IFN-gamma potentiate the deleterious effects of IL- 1 beta on mouse pancreatic islets mainly via generation of nitric oxide. Cytokine 6(4): 399-406.

26. Rubino F, Amiel SA, Zimmet P, Alberti G, Bornstein S, et al. (2020) NewOnset Diabetes in Covid-19. The New England journal of medicine. 